\title{
Late Quaternary Planktic Foraminifer Fauna and Monsoon Upwelling Records from the Western South China Sea, Near the Vietnam Margin (IMAGES MD012394)
}

\author{
Pai-Sen $\mathrm{Yu}^{1}$, Horng-Sheng $\mathrm{Mii}^{2}$, Masafumi Murayama ${ }^{3}$, and Min-Te Chen ${ }^{1, *}$ \\ ${ }^{1}$ Institute of Applied Geosciences, National Taiwan Ocean University, Keelung, Taiwan, ROC \\ ${ }^{2}$ Department of Earth Sciences, National Taiwan Normal University, Taipei, Taiwan, ROC \\ ${ }^{3}$ Center for Advanced Marine Core Research, Kochi University, Kochi, Japan
}

Received 8 June 2006, accepted 21 September 2007

\begin{abstract}
Marine sediment core MD012394 from the Vietnam coastal upwelling area in the western South China Sea was investigated in order to reconstruct the last Quaternary monsoon upwelling based on planktic foraminifer fauna assemblages and fauna-based sea surface temperature (SST) estimates. The age model of core MD012394 was constructed using oxygen isotope stratigraphy of the planktic foraminifer $G$. sacculifer, with 10 accelerator mass spectrometry (AMS) ${ }^{14} \mathrm{C}$ dating of planktic foraminifers from the sediment samples. Our studies on the relative and absolute abundances of planktic foraminifer assemblages reveal eight dominant species in core MD012394: N. dutertrei $+N$. pachyderma (right coiling), G. ruber, G. glutinata, G. sacculifer, P. obliquiloculata, G. menardii + G. tumida, G. calida, and G. inflata. In a Q-mode factor analysis of the fauna abundance data, the fauna factors show variations that do not parallel the glacial/interglacial changes throughout the last $135 \mathrm{kyr}$. The relative abundance patterns of G. inflata and $N$. dutertrei (including $N$. pachyderma-R) are interpreted as hydrographic proxies for East Asian summer and winter monsoon, respectively, in the current study. We calculated the fluctuations in the SST using the Revised Analog Method (RAM) in MD012394 and found that the abundance changes of the summer monsoon upwelling indicator $G$. inflata were similar and nearly synchronous. This suggests that the summer monsoon-driven upwelling signal was strong near the local summer insolation maximum, which induced low SSTs, particular around $\sim 11,33,59$, and $83 \mathrm{kya}$. Our studies support the view that the strengths of both summer insolation and the East Asian summer monsoon have determined the relative abundance of planktic foraminifers and the SSTs in the western SCS during the last $135 \mathrm{kyr}$.
\end{abstract}

Key words: South China Sea, Planktonic foraminifer fauna, Sea surface temperature, East Asian monsoon, Summer insolation Citation: Yu, P. S., H. S. Mii, M. Murayama, and M. T. Chen, 2008: Late quaternary planktic foraminifer fauna and monsoon upwelling records from the western South China Sea, near the Vietnam margin (IMAGES MD012394). Terr. Atmos. Ocean. Sci., 19, 347-362, doi: 10.3319/TAO. 2008.19.4.347(IMAGES)

\section{INTRODUCTION}

The South China Sea (SCS) is located between the Asian continent and the western Pacific warm pool and is one of the largest marginal seas along the western rim of the Pacific Ocean. The marine environment and climatic variations in the SCS are strongly affected by East Asian monsoons. The southwest (summer) monsoon lasts from June to September, whereas the stronger northeast (winter) monsoon prevails from November to March. Due to the thermal

\footnotetext{
* Corresponding author

E-mail:mtchen@mail.ntou.edu.tw
}

differences (different potential heating) between the Asian continent and the Pacific Ocean, the effects of the East Asian summer and winter monsoonal forcing are principal factors controlling the SCS surface hydrography and circulation. The monsoonal winds generate a seasonal reversal of the SCS surface currents. To a more regional extent, variations of the East Asian monsoon signatures in the SCS are well expressed in ocean responses to changes in the seasonal migrations of the Intertropical Convergence Zone (ITCZ). Cold-dry East Asian winter monsoons are strongest during the Northern Hemisphere winter when the 
ITCZ is in its southernmost position, whereas the warmhumid East Asian summer monsoons are strongest during the summer when the ITCZ is in its northernmost position (Wyrtki 1966, 1977).

Previous studies of the East Asian monsoon reconstruction based on western Pacific marine cores and terrestrial sediments (Chinese loess, stalagmite) concentrated on using stable isotope $\delta^{18} \mathrm{O}$ (Johnson et al. 2006), magnetic susceptibility (Chen et al. 1999; An et al. 2000, 2006; Porter 2001), clay minerals (Liu et al. 2003), planktic foraminifer and coccolith assemblages (Beaufort et al. 2003; Steinke et al. 2003; Chen et al. 2005), and micro-charcoal/pollen (Beaufort et al. 2003; Kershaw et al. 2003). Most previous reconstructions have shown that the East Asian winter monsoon has usually prevailed in the glacial stages and the summer monsoon reaches its maximum strength in most interglacial stages. Despite the glacial-interglacial contrast of the East Asian winter and summer monsoons, few studies have determined the precise strength and timing of the East Asian summer monsoon. Therefore, the pattern of East Asian monsoon variability, especially of the summer component, still requires more investigation of additional temporal and spatial scales.

The western SCS is a critical region for studying the summer component of the East Asian monsoon system because the sea surface temperature (SST), surface chlorophyll maximum, and primary production in this region are sensitive to changes in summer monsoon-driven upwelling (Fig. 1). Several records of the low-resolution planktic foraminifer assemblage analysis from the summer coastal
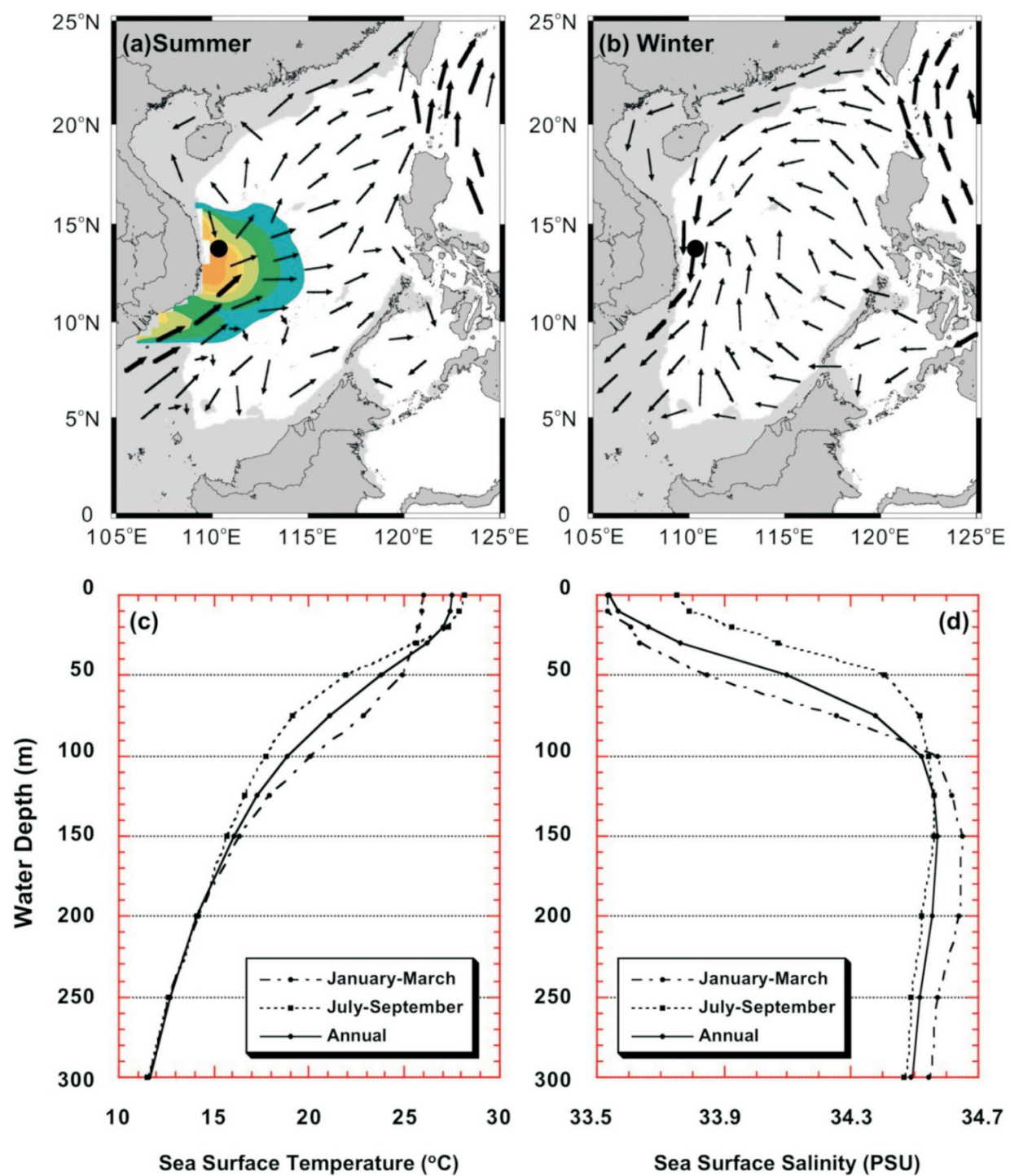

Fig. 1. Summer (a) and winter (b) prevailing seasonal surface currents (arrows) of the SCS. The seasonal wind direction generates a reversal of the SCS surface currents. Modern SST (c) and SSS (d) profiles for the annual mean, summer (July - September), and winter seasons (January - March). During the summer season, surface chlorophyll (up to $2-3 \mathrm{mg} \mathrm{m}^{-3}$ ) indicates that intensive coastal upwelling occurs along the Vietnamese coast. The circle symbol in (a) and (b) indicates the location of core MD012394. 
upwelling region have been reported (Jian et al. 2001; Huang et al. 2002). Although ice-volume forcing appears to be the primary forcing that is driving the hydrographic changes observed in the low-resolution records, the precise strength and timing of the monsoon variations are difficult to resolve due to the resolution limit of the records. Thus, high-resolution proxy records on orbital to sub-orbital scales are necessary for better reconstruction of monsoon variation in past glacial and interglacial stages.

In this study, we present a high-resolution reconstruction of monsoon variations based on a high sedimentation rate IMAGES (International Marine Global Change Study) core (MD012394), taken from the western SCS, near the Vietnam margins and close to the modern summer upwelling center. The core from this site recovers a complete sequence of a high sedimentation rate $\left(>15 \mathrm{~cm} \mathrm{kyr}^{-1}\right)$ and hemipelagic sediments of the past $\sim 280 \mathrm{kyr}$, and thus is ideal for constructing the history of the monsoon upwelling on orbital to sub-orbital time scales over the last glacial and interglacial stages. To investigate the East Asian monsoon variations recorded in the core sediments. We present preliminary data of planktic foraminifer fauna assemblages and fauna-based SST estimates of the past $\sim 135 \mathrm{kyr}$, which covers the last glacial and interglacial cycles of MIS (Marine Isotope Stage) 1 - 5, which is intended to reconstruct high-resolution hydrographic variations in the modern summer monsoon prevailing region. We concentrate on (1) documenting high-resolution variations in the planktic foraminifer assemblages of the past $135 \mathrm{kyr}$ in the western SCS; (2) applying and comparing multiple transfer function or analogue approaches for reconstructing SSTs; and (3) identifying possible mechanisms controlling the strength and timing of the East Asian summer/winter monsoon in the western SCS during the MIS 1 - 5 interval.

\section{OCEANOGRAPHIC SETTINGS}

The seasonally reversing monsoon wind plays an important role in forming the hydrographic features and patterns in surface circulation in the SCS. The East Asian monsoon wind in the SCS is southwesterly in summer and northeasterly in winter. Core MD012394, taken from the continental slope off the Vietnam margin $\left(13^{\circ} 47.54^{\prime} \mathrm{N}\right.$, $110^{\circ} 15.56$ ' E; water depth $2097 \mathrm{~m}$ ) is located in a monsoonaffected surface condition region of the SCS. From June to September, warm pool surface water of tropical Indian Ocean origin flows northward into the SCS and then forms an anticyclonic gyre mainly in the southern basin. When strong summer monsoon winds prevail parallel to the coastline, offshore Ekman transport induces a strong upwelling of cold, nutrient-rich waters off the Vietnam coast (Shaw et al. 1996). Due to the effect of coastal upwelling, the cold tongue is a prominent oceanic feature of monsoon-driven upwelling in the western SCS (Fig. 1). The upwelling process maintains a summer SST of $<28^{\circ} \mathrm{C}$ off the Vietnam margin, which is slightly lower than that in the entire SCS. The thermocline depth off the Vietnam margin is shallower than $30 \mathrm{~m}$ in peak summer seasons (WOA 1998), with higher salinity ( $>33.7 \mathrm{psu}$ ) indicating a subsurface upwelling (Fig. 1). Satellite ocean color images and the model simulations (Liu et al. 2002) reveal the effects of upwelling water that is well expressed by SST low, surface chlorophyll maximum (up to $2-3 \mathrm{mg} \mathrm{m}^{-3}$ ), and primary production maximum. In winter (between November and March), the northeast monsoon over the SCS drives a cyclonic gyre covering the entire basin with an intensified southward jet (the cold Chinese Coastal waters) along the coast of Vietnam (Wyrtki 1961; Shaw and Chao 1994). The surface water mass $(0-50 \mathrm{~m})$ near the Vietnam margin is characterized by a well-mixed layer with a temperature low to $\sim 26^{\circ} \mathrm{C}$ (Fig. 1). The winter temperature profile shows a deepened thermocline depth $(>70 \mathrm{~m})$ caused by strong mixing of surface and subsurface waters by the intensified East Asian winter monsoon. Observed from the historical hydrographic data, the subsurface structure in the western SCS during summer monsoon seasons appears to be characterized by a shallower thermocline and stronger subsurface upwelling than that during winter seasons. Therefore, the hydrographic conditions at the MD 012394 core location are influenced either by lateral advection from the upwelling center off Vietnam coast during the summer monsoon, or by mixed-layer deepening due to surface water cooling by northeasterly winds during the winter monsoon.

\section{DATA AND METHODS}

The sediments sampled and analyzed for this study are from a giant piston core, MD012394, collected during the IMAGES VII WEPAMA cruise in 2001 (Bassinot et al. 2002) and are archived in the National Core Repository and Laboratory located at the National Taiwan Ocean University. The MD012394 core location is at $13^{\circ} 47.54^{\prime} \mathrm{N}, 110^{\circ} 15.56^{\prime} \mathrm{E}$ with a water depth of $2097 \mathrm{~m}$ on the continental slope off the eastern Vietnam margin. The sediment is constituted of homogeneous grayish olive green to olive grey clay with calcareous nannofossil, foraminifer and diatom oozes. Because the core's location is above the present-day carbonate lysocline depth ( $3000 \mathrm{~m}$, Wang et al. 1999), the sediments feature good preservation of planktic foraminifer shells. We sampled the core at $5 \mathrm{~cm}$ intervals and $1 \mathrm{~cm}$ widths in order to cover the last $135 \mathrm{kya}$. This resulted in a maximum resolution of $\sim 300 \mathrm{yrs}$. A total of 630 samples from the core were prepared for planktic foraminifer stable isotope analyses, and 416 samples of the last 135 kya for planktic foraminifer assemblage analyses and SST reconstructions.

\subsection{Oxygen Isotope Analysis and AMS ${ }^{14} \mathrm{C}$ Dating}

The planktic foraminifer Globigerinoides sacculifer 
(without a saclike final chamber) was chosen for oxygen isotope analysis because of its persistent abundant presence in all samples and because its modern habitat is in the upper photic zone (Bé and Tolderlund 1971; Hemleben et al. 1989). We picked up 6 - 8 specimens of $G$. sacculifer in the $250-350 \mu \mathrm{m}$ size fraction for the isotope analysis. The foraminifers were soaked in $\mathrm{CH}_{3} \mathrm{OH}$ and $\mathrm{NaOCl}$ in order to remove any clay and organic matter attached with the shells. The foraminifer stable isotopes were analyzed in the MICROMASS mass spectrometer in the Stable Isotope Laboratory, National Taiwan Normal University. The analytical error $(1 \sigma)$ for $\partial^{18} \mathrm{O}$ is better than $\pm 0.007 \%$ and $\partial^{13} \mathrm{C}$ is better than $\pm 0.005 \%$. We report final values of the iso- tope data of each sample based on the average of two or three replicate measurements.

An age model for the upper sections of core MD012394 (Table 1; Fig. 2a) was developed using a total of 10 accelerator mass spectrometric (AMS) radiocarbon dated (at the laboratory in Nagoya University, Japan) planktic foraminifer samples. We used mixed G. ruber and/or G. sacculifer specimens for the age dating. The ${ }^{14} \mathrm{C}$ ages younger than $24 \mathrm{kya}$ have been calibrated to calendar year using the Radiocarbon Calibration Program REV 5.0 (Stuiver et al. 2005) and for older samples following the equations of Bard et al. (2004). A 400-year correction for the Pacific reservoir age has been applied for age dating. The MD012394 core samples

Table 1. Radiocarbon ages and marine isotopic events from the low-latitude stack used in core MD012394 chronology.

\begin{tabular}{|c|c|c|c|c|}
\hline Depth (cm) & AMS ${ }^{14} \mathrm{C}$ Age & Error $^{a}$ & Calendar Age (years) & Species/Age Model \\
\hline 14.5 & 832 & \pm 25 & 472 & G. ruber + G. sacculifer \\
\hline 64.5 & 2208 & \pm 26 & 1814 & G. ruber + G. sacculifer \\
\hline 169.5 & 4715 & \pm 29 & 4924 & G. ruber + G. sacculifer \\
\hline 304.5 & 9369 & \pm 35 & 10205 & G. ruber + G. sacculifer \\
\hline 359.5 & 10732 & \pm 37 & 12128 & G. ruber + G. sacculifer \\
\hline 434.5 & 13731 & \pm 43 & 15805 & G. ruber + G. sacculifer \\
\hline 539.5 & 15736 & \pm 49 & 18711 & G. ruber + G. sacculifer \\
\hline 644.5 & 19408 & \pm 60 & 22496 & G. ruber + G. sacculifer \\
\hline 774.5 & 24176 & \pm 83 & $27816^{\mathrm{b}}$ & G. ruber + G. sacculifer \\
\hline 849.5 & 27927 & \pm 105 & $31972^{b}$ & G. ruber + G. sacculifer \\
\hline 1141.5 & & & 52000 & MIS 3.3 \\
\hline 1299.0 & & & 62000 & MIS 4.2 \\
\hline 1516.5 & & & 79000 & MIS 5.1 \\
\hline 1641.5 & & & 86000 & MIS 5.2 \\
\hline 1811.5 & & & 97000 & MIS 5.3 \\
\hline 1871.5 & & & 106000 & MIS 5.4 \\
\hline 1959.0 & & & 122000 & MIS 5.5 \\
\hline 2081.5 & & & 133000 & MIS 6.2 \\
\hline 2879.0 & & & 194000 & MIS 7.1 \\
\hline 2931.5 & & & 202000 & MIS 7.2 \\
\hline 3009.0 & & & 213000 & MIS 7.3 \\
\hline 3181.5 & & & 225000 & MIS 7.4 \\
\hline 3349.0 & & & 236000 & MIS 7.5 \\
\hline 3439.0 & & & 242000 & MIS 8.0 \\
\hline 3494.0 & & & 248000 & MIS 8.2 \\
\hline 3574.0 & & & 258000 & MIS 8.3 \\
\hline 3691.0 & & & 266000 & MIS 8.4 \\
\hline
\end{tabular}

${ }^{a}$ Error is given in $1 \sigma$.

${ }^{b}$ Calendar ages have been calculated using a 400 year reservoir correction and applying the Stuiver et al. (2005) calibration curve for samples younger than 24000 calendar year in age and a U/Th calibration curve for the samples older than 24000 calendar years (Bard et al. 2004). 


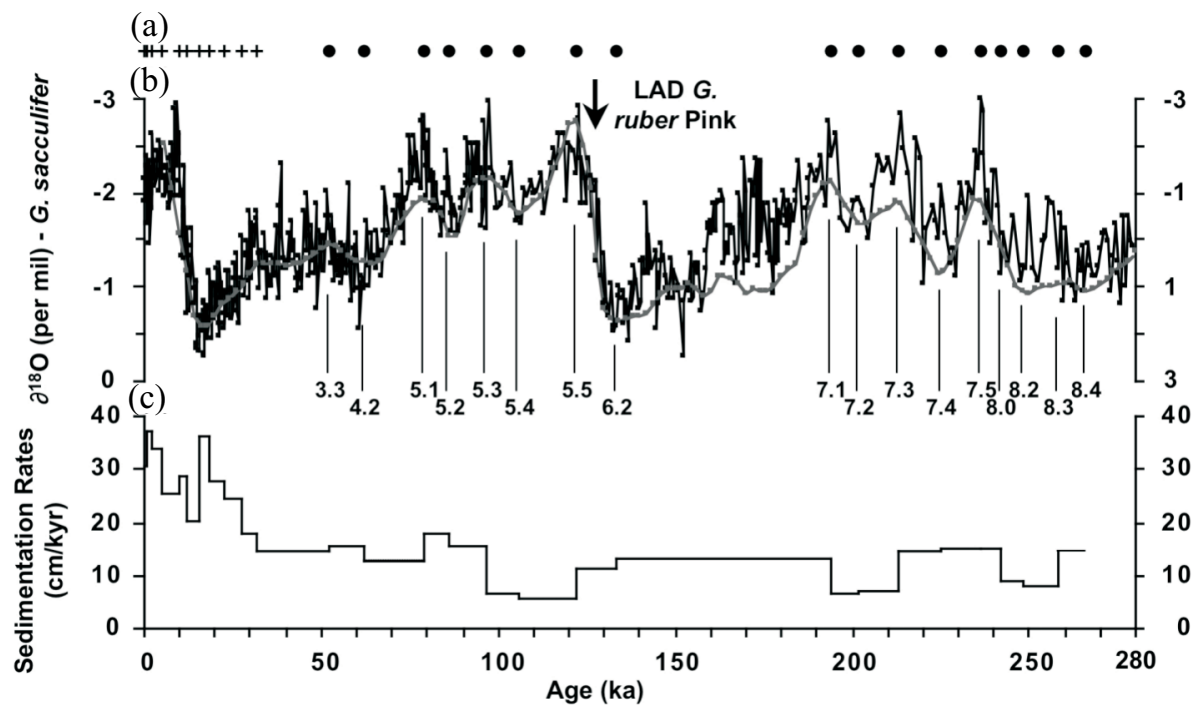

(d) Bandwidth for 200 lags on 623 values at $\Delta \mathrm{t}=0.45 \mathrm{kyr}$

$80 \%$ level coherency $\mathrm{Cl}$
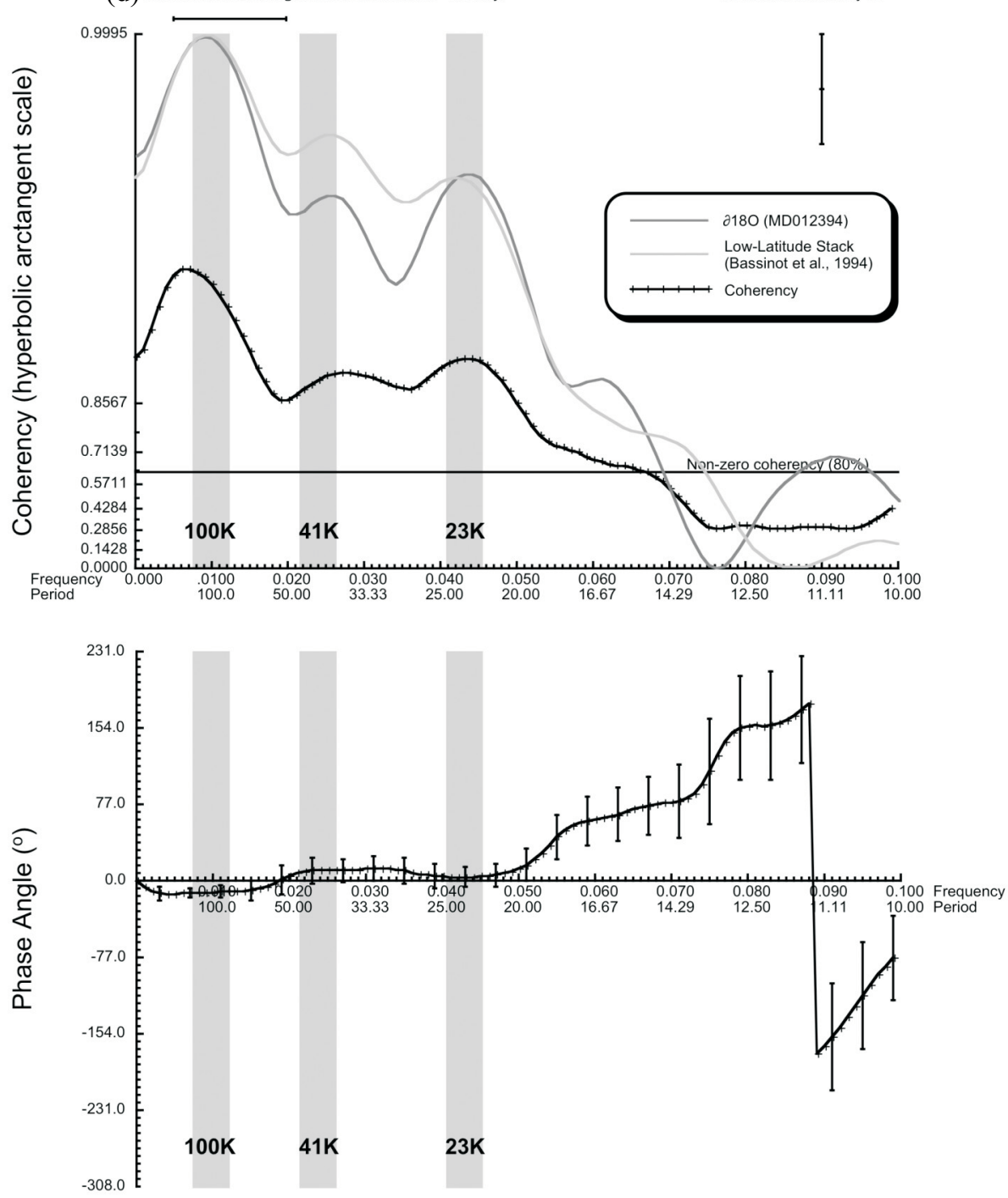

Fig. 2. (a) Position of AMS ${ }^{14} \mathrm{C}$ dates on planktic foraminifers converted to calendar ages (cross markers) and the low-latitude stack tie points used in the stratigraphy (solid circles); (b) MD012394 $\partial^{18} \mathrm{O}$ of planktic foraminifer results at $5 \mathrm{~cm}$ intervals (solid black line) compared with the low-latitude stack (gray line); (c) MD012394 sedimentation rate as reconstructed from $\mathrm{AMS}^{14} \mathrm{C}$ dates and age control points. The average sedimentation rate is 14 $\mathrm{cm} \mathrm{kyr}^{-1}$; (d) Cross-spectral results of the MD012394 $\partial^{18} \mathrm{O}$ record and low-latitude stack (Bassinot et al. 1994) show the presence of major orbital periodicity-100, 41, $23 \mathrm{ky}^{-1}$, and have a nearly in-phase pattern. 
at greater depth have been dated using oxygen isotope events by visual alignment of the $G$. sacculifer $\partial^{18} \mathrm{O}$ stratigraphy to the age control points of a low-latitude stack (Bassinot et al. 1994). Individual isotope events from MIS 3.3 to 8.4 were identified and tagged with the respective ages from Bassinot et al. (1994). The events used and their corresponding ages are listed in Table 1. A continuous timescale between two successive age control points was obtained by linear interpolation using the "ARAND" software of Howell (2001).

\subsection{Planktic Foraminifer Assemblages}

Samples of about $50 \mathrm{cc}$ each were processed using standard micropaleontological techniques (Chen et al. 1999) at the Earth Environment and Climate Variability Laboratory at the National Taiwan Ocean University. The samples for the analysis of the planktic foraminifer assemblages were freeze-dried under $24 \mathrm{~h}$. After being weighed, soaked in water, and washed through a $>63 \mu \mathrm{m}$ sieve using a weak spray of water, all samples were dried in an oven under $40^{\circ} \mathrm{C}$ overnight. To facilitate examination and counting of the planktic foraminifer species abundances, the $>150 \mu \mathrm{m}$ fraction was repeatedly split with the aid of a microspiltter until we had approximately 300 whole planktic foraminifer specimens per sample. The taxonomy of planktic foraminifer in this study follows the schemes in Parker (1962), Bé (1967), and Kipp (1976). This taxonomic scheme is consistent with previous SCS paleoceanographic studies based on planktic foraminifer fauna records (Chen et al. 1998, 1999; Chen and Huang 1998; Chen et al. 2003), in which three taxonomic categories Neogloboquadrina pachyderma (right coiling), pachyderma-dutertrei intergrade (P-D intergrade), and Neogloboquadrina dutertrei were combined in one unit Neogloboquadrina dutertrei. We also combined the two similar morphotypes Globorotalia menardii and Globorotalia tumida together into one unit. A total of 25 planktic foraminifer taxa were thus identified in this study. Fauna counts were then converted to relative abundances and absolute abundances for all identified species of planktic foraminifers. We also applied a Q-mode factor analysis (Imbrie and Kipp 1971) to the MD012394 fauna percentage data to extract the fewest statistically independent end members for modeling the maximum information preserved in the data.

\subsection{SST Reconstructions from Multi-Technique Approaches}

In order to reconstruct the hydrographic changes associated with monsoon upwelling along the Vietnam coast over the past $135 \mathrm{kyr}$, we have applied the Revised Analog Method (RAM) (Waelbroeck et al. 1998). The RAM is considered to be a reliable method for reconstructing western
Pacific SST based on planktic foraminifer fauna assemblages (Chen et al. 2005). Precise SST reconstructions from planktic foraminifer records rely on a high-quality calibration database. In this study, we adopted a western Pacific coretop database of 694 samples, which were compiled from the MARGO project (Chen et al. 2005; Kucera et al. 2005). MD012394 SST estimates were performed using the standard routines of the RAM. The potential biases in the calibration of the RAM techniques in the western Pacific database have been presented elsewhere (Chen et al. 2005). In particular, the errors associated with the use of the RAM for estimating SST have been demonstrated to be $<1^{\circ} \mathrm{C}$ with the application of the western Pacific coretop database (Chen et al. 2005).

\section{RESULTS}

\subsection{Oxygen Isotope Stratigraphy and Sedimentation Rate}

The high-resolution $\partial^{18} \mathrm{O}$ record of the planktonic foraminifer G. sacculufer (Fig. 2b) reveals that glacial/interglacial variations of $1.5 \%$, in agreement with previous results (Thunell et al. 1992; Schonfeld and Kudrass 1993; Lee et al. 1999; Chen et al. 2005; Zhao et al. 2006). The mean values ( - 2.11\%o) for MIS 5 and Holocene (0 - $4 \mathrm{ka}$ ) are also consistent with previously reported data. The oxygen isotopic stratigraphy of MD012394 (Fig. 2b) indicates 4 glacial-interglacial oscillations from MIS 8 to MIS 1 from 280 kya to the present. Cross-spectral analysis was performed with the software ARAND in order to examine the variance distribution in the frequency domain and phase relationships between the MD012394 oxygen isotope curve and the low-latitude stack. The time series was first interpolated at $0.45 \mathrm{ky}$ intervals and the analyses were performed on a series of 623 data points extending to 280 kya. For cross-spectral analysis, 200 lags were used, giving a bandwidth of 0.015 cycle $\mathrm{kyr}^{-1}$. The phase spectra were calculated at the $80 \%$ confidence level and were only shown at those frequencies at which coherencies were significant. The cross-spectra (Fig. 2d) show that the MD012394 $\partial^{18} \mathrm{O}$ time series contains peak variance in major orbital frequency bands centered at the $100 \mathrm{kyr}^{-1}$ (eccentricity), $41 \mathrm{kyr}^{-1}$ (tilt), and $23 \mathrm{ky}^{-1}$ (precession) periods, and are significantly coherent $(>0.90)$ with the low latitude stack. The two time series are nearly in phase at the orbital frequencies. This suggests that the MD012394 $\partial^{18} \mathrm{O}$ record is successfully correlated with the $\partial^{18} \mathrm{O}$ time scale of the low latitude stack. The last appearance datum of G. ruber pink at 2014 cm occurs at Termination II $(\sim 127 \mathrm{ka}$, Thompson et al. 1979) (Fig. 2b), strengthening the validity of the age model. The calculated sedimentation rates (Fig. 2c) based on this age model range from $\sim 30 \mathrm{~cm} \mathrm{kyr}^{-1}$ during the last $28 \mathrm{kya}$ to lower values in the order of $\sim 7 \mathrm{~cm} \mathrm{kyr}^{-1}$. These average sedimentation rates provide a temporal resolution of approxi- 
mately 130 to 910 years at a sample spacing of $5 \mathrm{~cm}$. The anomalously highest sedimentation rates estimated for the top $850 \mathrm{~cm}$ (equal to $\sim 28 \mathrm{ka}$ ) of the record are most likely due to the stretching effect of the top part of the core collected through giant piston coring by the R/V Marion Dufresne (Szeremeta 2000). Although sedimentation rates in the SCS and Sulu Sea were reportedly increased during glacial periods and decreased during interglacial stages (Chen and Huang 1998; de Garidel-Thoron et al. 2001), our record shows more constant sedimentation rates with variations irrespective of glacial and interglacial stages. Relatively high sedimentation rates are observed in MIS 2, MIS 5.1 to 5.3, MIS 6, and MIS 7.3 to 7.5 (Fig. 2c). The sources of sediments at this site appear to be complex. Various components including terrestrial inputs from the Vietnam shelves and slopes, suspended sediments brought by the Chinese Coastal Current, riverine input from the Pearl and Mekong, and biogenic carbonate and opal all seem to be important, resulting in sedimentation rates which are independent of glacial and interglacial changes.

\subsection{Planktic Foraminifer Abundances}

Large downcore variations in the relative and absolute abundances of the dominant planktic foraminifer species indicate significant variability in the environmental conditions in this region throughout the past 135 kyr. Descriptive statistics of the relative abundances of 25 species of planktic foraminifer fauna were calculated for the last $135 \mathrm{kyr}$ record, which consists of 416 downcore faunal abundance data (Table 2). The relative abundances of eight important species are presented here in order to examine the changes in

Table 2. Planktic foraminiferal taxonomic categories used in the present study along with their means, standard deviations, and minimum and maximum in core MD012394.

\begin{tabular}{lcccc}
\hline \multicolumn{1}{c}{ Foraminifer species } & Mean (\%) & St. Dev. (\%) & Minimum (\%) & Maximum (\%) \\
\hline Orbulina universa & 1.64 & 0.89 & 0.00 & 7.80 \\
Globigerinoides conglobatus & 0.79 & 0.68 & 0.00 & 3.86 \\
Globigerinoides ruber & 20.44 & 4.39 & 9.42 & 37.50 \\
Globoturborotalita tenella & 2.10 & 1.12 & 0.00 & 8.10 \\
Globigerinoides sacculifer & 8.81 & 4.42 & 1.36 & 21.83 \\
Sphaeroidinella dehiscens & 0.22 & 0.27 & 0.00 & 1.24 \\
Globigerinella aequilateralis & 2.06 & 0.90 & 0.00 & 5.65 \\
Globigerinella calida & 5.34 & 1.65 & 0.72 & 10.37 \\
Globigerina bulloides & 4.41 & 1.60 & 1.06 & 11.11 \\
Globigerina falconensis & 0.43 & 0.40 & 0.00 & 2.27 \\
Beela digitata & 0.87 & 0.54 & 0.00 & 3.01 \\
Globoturborotalita rubescens & 1.28 & 0.99 & 0.00 & 6.32 \\
Neogloboquadrina pachyderma (L) & 0.03 & 0.09 & 0.00 & 0.61 \\
Neogloboquadrina dutertrei & 22.24 & 8.94 & 6.34 & 50.34 \\
Globoquadrina conglomerata & 0.26 & 0.41 & 0.00 & 3.46 \\
Globorotaloides hexagonus & 0.02 & 0.07 & 0.00 & 0.90 \\
Pulleniatina obliquiloculata & 5.68 & 2.24 & 0.00 & 11.83 \\
Globorotalia inflata & 3.96 & 2.97 & 0.00 & 17.52 \\
Globorotalia truncatulinoides (L) & 0.24 & 0.77 & 0.00 & 6.38 \\
Globorotalia truncatulinoides (R) & 0.55 & 0.93 & 0.00 & 5.00 \\
Globorotalia crassaformis & 1.84 & 1.90 & 0.00 & 8.81 \\
Globorotalia hirsuta & 0.05 & 0.16 & 0.00 & 1.34 \\
Globorotalia scitula & 1.67 & 1.21 & 0.00 & 6.36 \\
Globorotalia menardii (+Globorotalia tumida) & 5.60 & 2.94 & 0.30 & 18.38 \\
Globigerinita glutinata & 9.48 & 3.38 & 2.82 & 23.30 \\
\hline Not Neglob & &
\end{tabular}

Note: Neogloboquadrina dutertrei include Neogloboquadrina pachyderma (R) and pachyderma - dutertrei intergrade. 
sea surface conditions and climatic changes recorded in MD012394. These eight species constitute more than 70\% of the planktic foraminifer composition. These are: $N$. dutertrei $+N$. pachyderma (right coiling) $(22 \%)$, G. ruber (20\%), G. glutinata (10\%), G. sacculifer (9\%), P. obliquiloculata (6\%), G. menardii + G. tumida (6\%), G. calida $(5 \%)$, and G. inflata (4\%). Downcore variations in the relative (solid line) and absolute abundances (gray line) of each of these eight dominant species are presented (Fig. 3), to- gether with $\partial^{18} \mathrm{O}$ of $G$. sacculifer for comparison.

$N$. dutertrei $+N$. pachyderma (right coiling) has been widely used for paleoceanographic reconstructions in cold oceans (Bé 1977; Bé and Hutson 1977; Hemleben et al. 1989), common in active current systems, strong upwelling with strong stratification in water columns, and/or high nutrient contents, especially concentrated in the outer margin of the subtropical gyres of the western Pacific (Pflaumann and Jian 1999). It is considered to be a typical East Asian

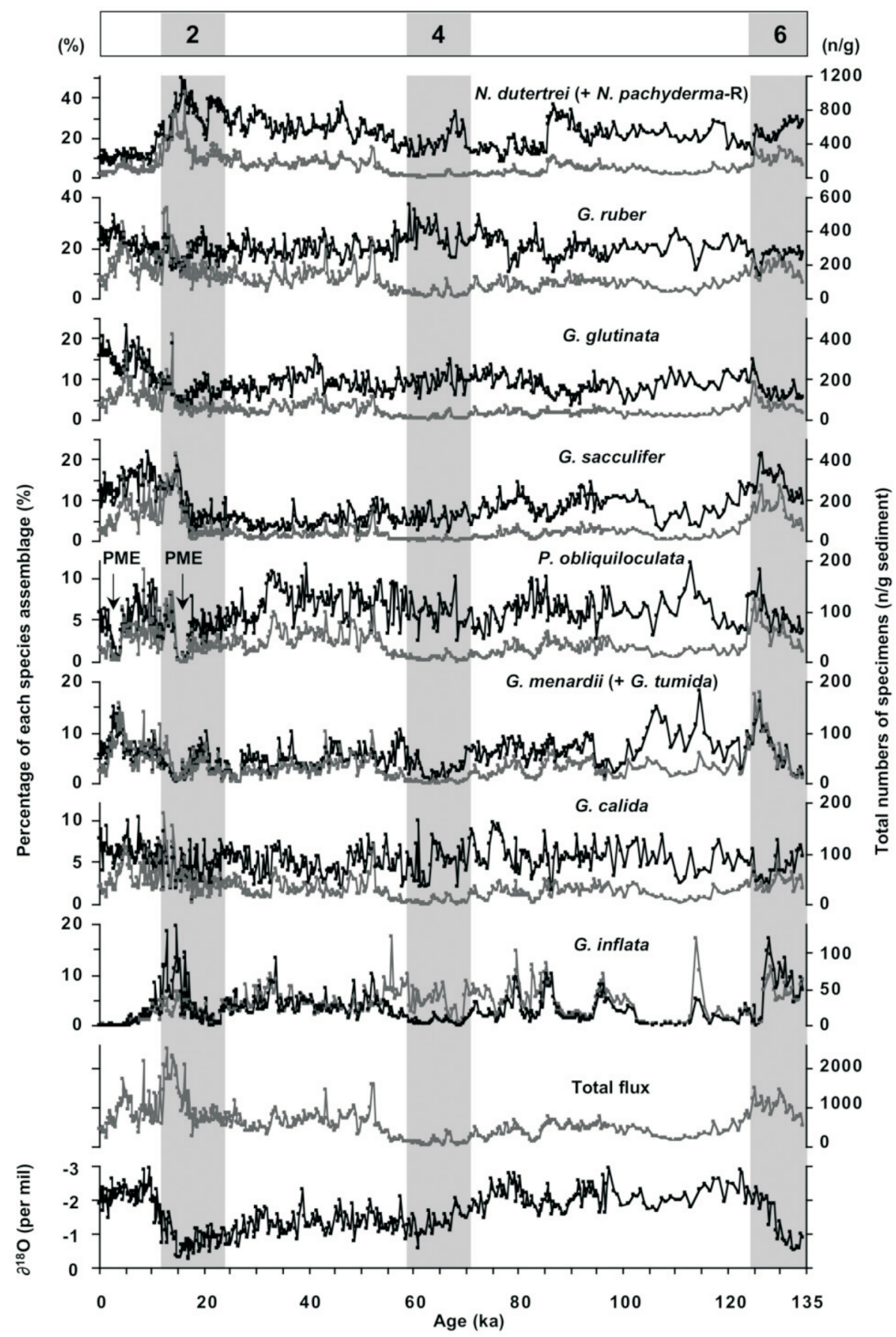

Fig. 3. Relative and absolute abundances of the eight dominant species for the last $135 \mathrm{ka}$, plotted against age and compared to downcore $\partial^{18} \mathrm{O}$ stratigraphy. Shaded intervals indicate glacial periods. 
winter monsoon indicator in the SCS (Jian et al. 2001; Huang et al. 2002). The highest relative abundance of $N$. dutertrei $+N$. pachyderma (right coiling) at the MD012394 core site may account for the cold water masses and strong mixing brought by the Chinese Coast Current during strong East Asian winter monsoon conditions. N. dutertrei $+N$. pachyderma (right coiling) are the most dominant species in core MD012394 with maximum relative abundances near $50 \%$ and a mean of $22 \%$ (Fig. 3). In general, the lowest relative abundances for this species appear at glacial/interglacial transitions. Notable increases in the relative abundances occurred during the MIS 2, late MIS 3, early MIS 4, and middle MIS 5. The relative abundance of $N$. dutertrei $+N$. pachyderma (right coiling) correlates well with their absolute abundance. Except for the highest absolute abundances (up to $1000 \mathrm{n} \mathrm{g}^{-1}$ sediment) during the MIS 2, N. dutertrei + $N$. pachyderma (right coiling) yields the lowest flux $\left(<100 \mathrm{n} \mathrm{g}^{-1}\right.$ sediment), covering almost all the temporal variation.

G. ruber, G. glutinata, and G. sacculifer are generally considered to be spinose and algal-bearing symbionts (Hemleben et al. 1989). The three species are typical tropical/subtropical species inhabiting warm, well-stratified surface water (Bé 1977; Fairbanks et al. 1982; Hemleben et al. 1989; Patrick and Thunell 1997). In contrast to $N$. dutertrei, these warm-water/mixed layer species have the second highest dominant abundances in core MD012394. During the past $135 \mathrm{kya}$, these three warm-water species exhibit no clear glacial/interglacial patterns. In general, G. ruber shows larger fluctuations with a range of $10-38 \%$, which is greater than those of G. glutinata (3 to 23\%) and G. sacculifer (1 to $23 \%$ ). Larger relative abundance changes of these three species occurred during the MIS 1 to MIS 2 and during MIS 4 to MIS 5 to a lesser extent.

P. obliquiloculata is a species indicating warm water mass and/or deep thermocline conditions in the open ocean environment of the western Pacific (Chen and Prell 1997). The abundances of this species are higher in the northern SCS (> 10\%) (Pflaumann and Jian 1999). In the SCS, $P$. obliquiloculata is thought to reflect conditions within the bottom of the mixed layer and/or in the uppermost part of the thermocline (Steinke and Chen 2003). In MD012394, the relative abundances of $P$. obliquiloculata range from 0 to $12 \%$, with a mean of $6 \%$. There are two distinct minimum events during the late Holocene ( $\sim$ to $3 \mathrm{kyr} \mathrm{BP}$ ) and near the LGM ( 17 to 15 kyr BP) (Fig. 3). The "Pulleniatina minimum event" (PME) has been well documented from core studies in the Ryukyu Arc region (Ujiié et al. 1991; Li et al. 1997; Ujiié and Ujiié 1999) and the SCS (Jian et al. 1996; Steinke and Chen 2003; Lin et al. 2006). Previous studies have attributed the effect of diminished Kuroshio water to the PME, occurring from $\sim 4500$ to 3000 yrs BP without a cooling signature (Ujiié et al. 2003). The similar PME type of events found in SCS cores, therefore, indicate a change of more regional scale, and may suggest that hydrographic con- dition changes could be responsible for the event. Another PME (from 17000 to 15000 yrs BP) in our core is concurrent with the timing of the first Heinrich event, possibly suggesting a climatic/oceanic linkage between the SCS and the Northern Hemisphere high latitudes.

G. menardii (including G. tumida) occurs in subtropical to tropical water masses with a clear maximum in the relative abundances in the equatorial and tropical seas. In MD012394, this species appears in high abundance ( $>20 \%$ ) in both glacial and interglacial stages, such as in the middle MIS 1, MIS 2, early MIS 5, and late MIS 6 (Fig. 3). More interestingly, G. calida also shows no clear glacial/interglacial pattern in MD012394 (Fig. 3).

$G$. inflata is an indicator for transitional and subpolar water, preferring to live in the bottom of thermocline depths (Bé 1977; Hemleben et al. 1989). High abundances of $G$. inflata occur in surface sediments located in weakly-stratified water columns, and strong coastal upwelling regions, i.e., the Peru Current in the southeastern Pacific (Feldberg and Mix 2002). In MD012394, this species appears in high abundance $(>10 \%)$ in several short episodes near 11, 33, 59, and 83 kya (Fig. 3) and exhibits no clear glacial or interglacial relationship.

In this study, we calculated the absolute abundances of each dominant planktic foraminifer (Fig. 3). Foraminifer counts were converted to absolute abundances of each identified species per dry weight sediment (g). The total absolute abundances of planktic foraminifers show a distinct maximum ( $2500 \mathrm{n} \mathrm{g}^{-1}$ sediments) during the Termination I and a minimum $\left(<200 \mathrm{n} \mathrm{g}^{-1}\right.$ sediments $)$ in MIS 4. This first order pattern of the total absolute abundances may reflect carbonate preservation and terrestrial sediment dilution, which are not related to hydrographic changes in the western SCS.

\subsection{Fauna Factor Analysis}

Here we performed a Q-mode VARIMAX factor analysis, which has been widely used for paleoenvironmental reconstructions (Imbrie and Kipp 1971), in order to extract any major faunal components not obvious from calculating the most abundant species. Twenty-five species were selected for Q-mode factor analysis based on their relative abundances. We found that three factors account for $\sim 95 \%$ of the total variance of the analyzed samples. The first factor explains $49 \%$ of the total variance and is entirely dominated by $N$. dutertrei and N. pachyderma (right coiling) (Table 3). G. ruber, G. glutinata, and G. sacculifer characterize Factor 2 (43\% of the total variance). G. inflata and P. obliquiloculata characterize Factor 3 but only explain $2 \%$ of the total variance. Although $G$. inflata is a minor species when considering its average abundance in the total fauna assemblages, this species' abundances show episodic oscillations that are well-above the significant level ( $>\sim 10 \%$; Fig. 3). All of the downcore records have a communality of $>0.95$, indicating 
Table 3. Varimax factor scores derived from Q-mode factor analysis of the planktic foraminiferal census data in core MD012394. Planktic foraminiferal species exhibit high factor scores that are highly correlated with the first three factors.

\begin{tabular}{lccc}
\hline \multicolumn{1}{c}{ Foraminifer species } & F1 & F2 & F3 \\
\hline Orbulina universa & 0.023 & 0.037 & 0.009 \\
Globigerinoides conglobatus & 0.000 & 0.030 & 0.030 \\
Globigerinoides ruber & 0.118 & $\underline{0.668}$ & -0.138 \\
Globoturborotalita tenella & 0.014 & 0.060 & 0.053 \\
Globigerinoides sacculifer & 0.025 & $\underline{0.469}$ & 0.160 \\
Sphaeroidinella dehiscens & -0.004 & 0.013 & 0.016 \\
Globigerinella aequilateralis & 0.015 & 0.072 & 0.025 \\
Globigerinella calida & 0.043 & 0.178 & 0.045 \\
Globigerina bulloides & 0.048 & 0.127 & -0.030 \\
Globigerina falconensis & 0.006 & 0.015 & -0.017 \\
Beela digitata & 0.009 & 0.028 & 0.006 \\
Globoturborotalita rubescens & 0.020 & 0.029 & -0.037 \\
Neogloboquadrina pachyderma $(\mathbf{L})$ & 0.002 & -0.001 & 0.001 \\
Neogloboquadrina dutertrei & $\underline{0.986}$ & -0.108 & -0.039 \\
Globoquadrina conglomerata & 0.004 & 0.008 & -0.002 \\
Globorotaloides hexagonus & 0.000 & 0.001 & -0.001 \\
Pulleniatina obliquiloculata & 0.051 & 0.100 & $\underline{0.424}$ \\
Globorotalia inflata & 0.031 & -0.039 & $\underline{0.796}$ \\
Globorotalia truncatulinoides $(\mathbf{L})$ & 0.001 & 0.006 & 0.029 \\
Globorotalia truncatulinoides $(\mathbf{R})$ & -0.004 & 0.037 & 0.044 \\
Globorotalia crassaformis & 0.038 & -0.026 & 0.176 \\
Globorotalia hirsuta & 0.001 & 0.000 & 0.009 \\
Globorotalia scitula & 0.050 & 0.014 & -0.046 \\
Globorotalia menardii $(+$ Globorotalia tumida) & -0.006 & 0.218 & 0.272 \\
Globigerinita glutinata & -0.009 & $\underline{0.449}$ & -0.144 \\
\hline Variance (\%) & 48.938 & 43.239 & 2.146 \\
Cumulative Variance (\%) & 48.938 & 92.177 & 94.323 \\
\hline Neoglobon. & & &
\end{tabular}

Note: Neogloboquadrina dutertrei include Neogloboquadrina pachyderma (R) and pachyderma - dutertrei intergrade.

that these three factors capture the major fauna variations in core MD012394.

\subsection{SST Estimations}

Over the last $135 \mathrm{kyr}$, the foram-based SST estimations have a range of 22 to $28^{\circ} \mathrm{C}$ (Fig. 4). The SST ranges are in good agreement with previously reported values for the SCS (Steinke et al. 2001; Chen et al. 2005). Three features of the SST records are important to note. First, we have attempted to evaluate the sensitivity of the SST estimation methods on the basis of communality and dissimilarity and/or similarity. The SST estimates indicate that the downcore samples are well explained by factor models or have good analogues in the western Pacific calibration database (Fig. 4). Relatively low communality or the lack of a good analogue in estimating glacial (i.e., MIS 2) or low SST samples could be due to the lack of suitable analogues from temperate to subpolar regions in the western Pacific calibration database. The highest-quality estimates are in the youngest interval ( 0 - $10 \mathrm{kya})$, indicating that the RAM yields reliable estimates of relatively high SSTs. Second, the modern observations of annual mean SST (WOA 1998) at this core site is $27.4^{\circ} \mathrm{C}$. Our SST estimates of the annual mean from the coretop sample are in good agreement with modern SSTs. Third, the RAM SST estimates for the MIS 5 yield frequent, large amplitude cooling $\left(\sim 2-3^{\circ} \mathrm{C}\right)$, which is more pronounced than that for the period from the LGM to the Holocene. These larger cool- 


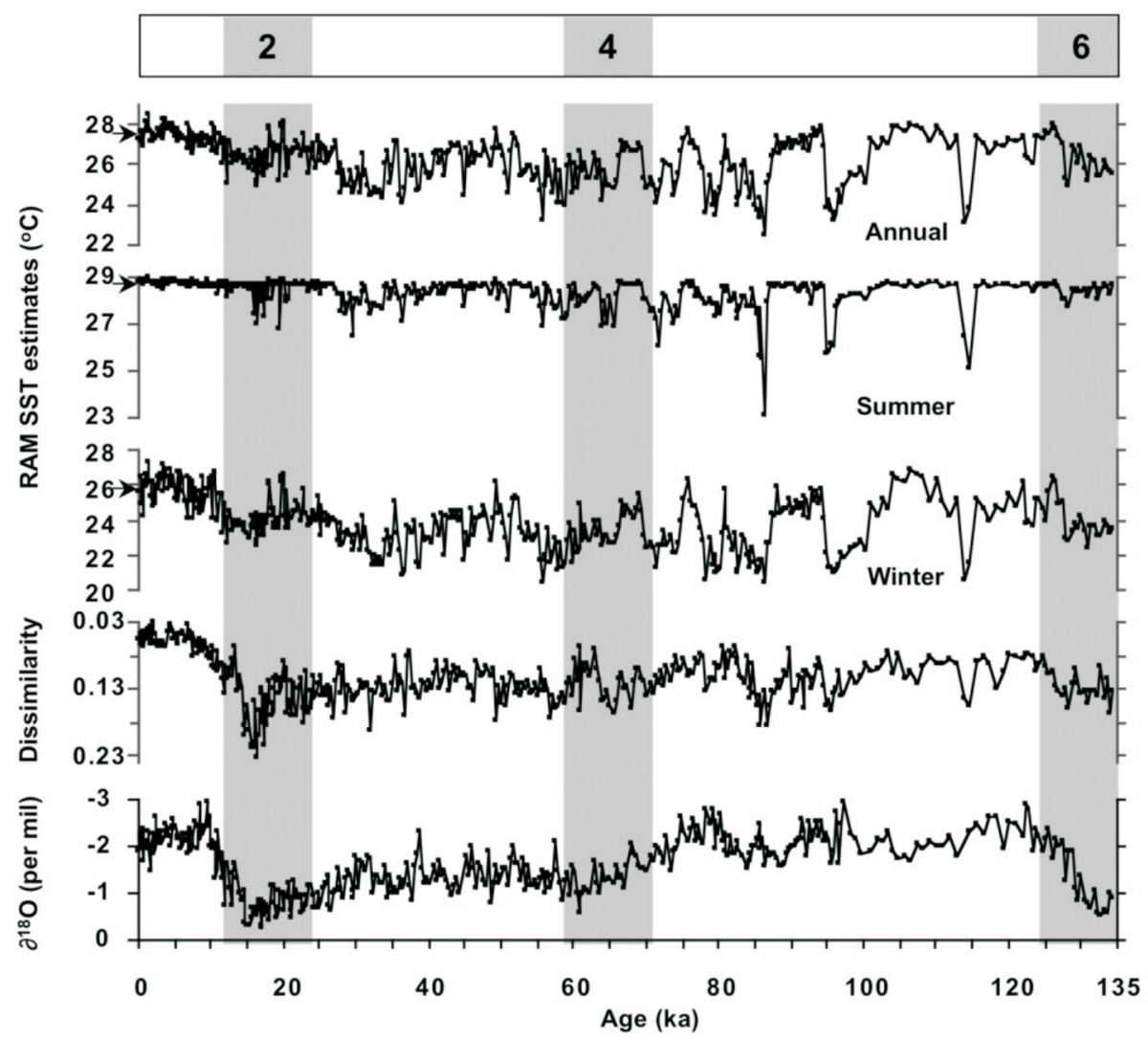

Fig. 4. A RAM approach to SST estimations, including annual, summer season, winter season, and dissimilarity, applied to the core MD012394, plotted against age and compared to downcore $\partial^{18} \mathrm{O}$ stratigraphy. Shaded intervals indicate glacial periods.

ing events during MIS 5 imply important hydrographic changes driven by regional climatic mechanisms such as monsoon or surface current in the western SCS.

\section{DISCUSSION}

\subsection{Planktic Foraminifer Assemblages and East Asian Summer/Winter Monsoons}

Although paleoclimatic studies of East Asian summer/ winter monsoon have produced a wide range of results from terrestrial (Chinese loess and stalagmite) and marine cores (clay minerals, micro-charcoal abundances, microfossil assemblages) (Beaufort et al. 2003; Liu et al. 2003; Yuan et al. 2004; Sun et al. 2005; Yu et al. 2006), little is known about the summer/winter monsoon signals recorded in marine microfossils, especially in planktic foraminifer assemblages. Previous SCS studies only suggest that ice-volume forcing/sea level is a primary factor in determining the strength and timing of the East Asian monsoon (Jian et al. 2001; Huang et al. 2002). In this simple scenario, the East Asian winter monsoon prevailed in glacial stages and the summer monsoon reached maximum strength during interglacial stages.

Our new data from the MD012394 planktic foraminifer fauna record, however, suggest a more complicated sce- nario. The species abundances of $N$. dutertrei and $N$. pachyderma-R as indicated by Factor 1 loadings are relatively high in some broad time intervals of $\sim 22,45,71$, and 94 kya (Fig. 5). Moreover, the abundances of $G$. inflata as indicated by Factor 3 loadings are relatively high at short episodes of $\sim 11,33,59,83$ kya (Fig. 5). The abundance patterns of both species exhibit no clear relationship with respect to glacial and interglacial changes. Therefore, the interpretation of simple monsoon-ice volume linkage in previous studies appears to be invalid for our observations.

In the region of the present study, mixing and subsurface upwelling are observed in both winter and summer seasons. Vertical mixing and surface chlorophyll maximums are particularly well developed in the summer (Kuo et al. 2000; Liu et al. 2002), when summer monsoon winds prevail along the eastern Vietnamese coast and induce upwelling. Taking the modern observation as a key to the past, we suggest that the increased abundances of $N$. dutertrei $(+N$. pachyderma-R) relative to $G$. inflata, or vice versa, are due to the increased strength of East Asian winter or summer monsoons driven by orbital variations in the past $100 \mathrm{kyr}$. The relative abundance patterns of the foraminifer species in core MD012394 can thus be interpreted as a proxy for the mixing and/or upwelling intensity in response to winter or summer monsoon variations in the western SCS during the past $100 \mathrm{kyr}$. 


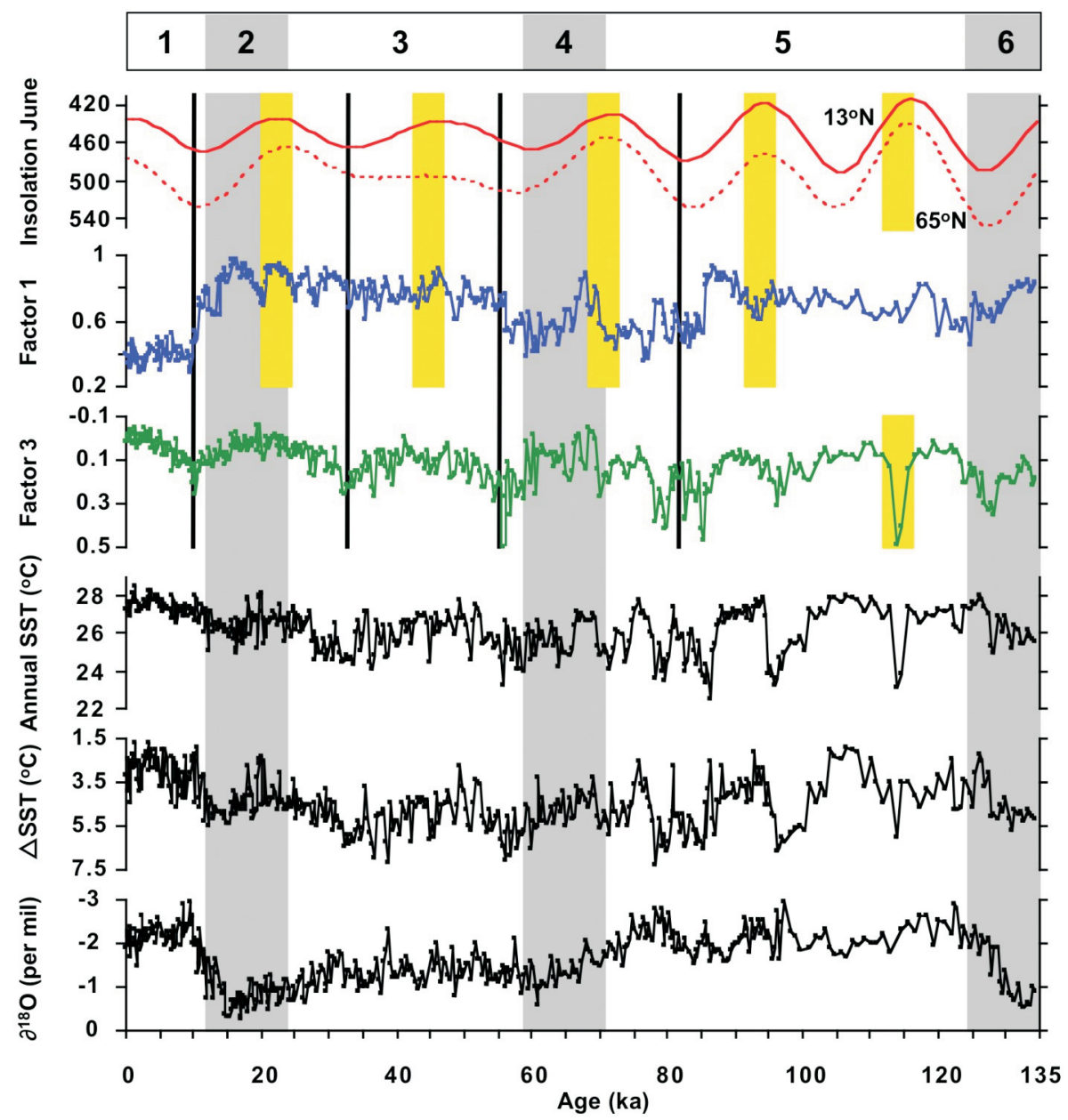

Fig. 5. Insolation curve calculated for the month of June at $13^{\circ} \mathrm{N}$ (Solid red line), at $65^{\circ} \mathrm{N}$ (dashed red line), Factor 1 loadings ( $N$. dutertrei, solid blue line), faunal Factor 3 loadings ( $G$. inflata, Solid green line), annual SST and $\Delta$ SST at core MD012394 over the last $135 \mathrm{ky}$. Both factor loadings and SST estimations do not vary significantly with the glacial/interglacial periods but are clearly associated with the summer insolation curves. The faunal Factor 3 loadings and SST estimations increased during the periods of the high summer insolation (indicated by solid lines in black), which had maxima around $\sim 11,33,59$, and 83 kya, whereas Factor 1 loadings increased during the periods of low summer-insolation peaks around $\sim 20-25$, 43 - 48, 68 - 73, 92 - $97 \mathrm{kya}$ (indicated by shadows in yellow). In particular, Factor 3 loadings increased to their maximum values during 112 - $117 \mathrm{kya}$, when the summer insolation reached its minima.

Our fauna and SST variations show different patterns from that reconstructed from an alkenone record from the southern SCS (Zhao et al. 2006), probably due to more subsurface and/or upwelling influences on the fauna assemblages, and different sensitivity of SST estimation techniques based on planktic foraminifer faunas and coccolith floras.

\subsection{Summer Insolation and Fauna SST in the SCS}

We compared the summer insolation curves at $13^{\circ} \mathrm{N}$ and $65^{\circ} \mathrm{N}$, the relative abundances of two upwelling species $[N$. dutertrei $(+N$. pachyderma-R) and $G$. inflata] as indicated by Factor 1 and Factor 3 loadings, respectively, and the RAM SSTs of annual mean and seasonality $(\triangle \mathrm{SST}$ calculated by from the difference between summer and winter SSTs) (Fig. 5). The summer insolation changes in the past $135 \mathrm{kyr}$ are mainly controlled by precession forcing, which displays $\sim 21$ kyr cycles. This comparison shows that the relative abundances of $N$. dutertrei $(+N$. pachyderma-R) reach maxima during broad time intervals of lower Northern Hemisphere summer insolation at 22, 45, 71, and 94 kya. The strength of the East Asian winter monsoon has been assumed to reach its maxima during these intervals by a "cross-hemisphere flow" mechanism (Yu et al. 2006). Consistent with this interpretation, we suggest that the abundances of $N$. dutertrei $(+N$. pachyderma-R) are indicative of East Asian winter monsoon strength. In contrast, the abundances of $G$. inflata are increased with low annual mean SST and high seasonality during short periods of higher Northern Hemisphere summer insolation centered at $\sim 11$, 33,59 , and 83 kya. The insolation patterns during these time intervals correspond to the expression of large seasonality in the SCS climate, and the condition favors the increased strength of the East Asian summer monsoon. The strong 
summer monsoon wind is induced by a large sensible heating on the East Asian continent. Strong ascending air on the continent intensifies strong southwesterly winds from the sea into East Asia. When the strong southwesterly currents reach the eastern coast of Vietnam, active upwelling associated with cooling in regional coastal water developed during the summer and left imprints in our planktic foraminifer assemblages.

In particular, we observed that the SST decreased to very low values near $\sim 114$ kya when the Northern Hemisphere summer insolation reached a minimum. The large SST decrease appears to be influenced by greater East Asian winter monsoon intensity, also through the "cross-hemisphere flow" mechanism (Yu et al. 2006), whereas warm/ humid vegetation and climate have been observed in the Southern Hemisphere (van der Kaars and Deckker 2002). Furthermore, high sea level conditions at this interglacial stage may also favor stronger Chinese Coastal Current flow across the Taiwan Straits, bringing cold water from the north to the SCS.

\section{CONCLUSIONS}

We analyzed a high-resolution record of planktic foraminifer fauna abundances from IMAGES core MD012394 of the past $135 \mathrm{kyr}$ taken from the Vietnam margin. The fauna variations were interpreted to reflect hydrographic changes in response to East Asian summer/winter monsoons. We draw the following conclusions based on this record:

1. Our analyses of MD012394 planktic foraminifer faunal records indicate that $N$. duterteri $+N$. pachyderma-R, $G$. ruber, G. sacculifer, G. glutinata, and G. inflata are the dominant species and represent good water mass indicators in the monsoon upwelling regions of the western SCS;

2. The abundances of $N$. dutertrei and $N$. pachyderma-R as indicated by Factor 1 loadings were relatively high in some broad time intervals of cold periods near $\sim 22,45$, 71, and 94 kya, when Northern Hemisphere summer insolation levels were low. The fauna assemblages are primarily indicative of East Asian winter monsoon strength, which was driven by a "cross-hemisphere flow" mechanism proposed by Yu et al. (2006);

3. The abundances of $G$. inflata as indicated by Factor 3 loadings showed abruptly high values at short cooling episodes centered at $\sim 11,33,59$, and $83 \mathrm{kya}$. The high abundances of $G$. inflata appear to coincide with Northern Hemisphere summer insolation maxima, which favor the development of stronger southwesterly and monsoon upwelling along the Vietnam margin. Our studies support the view that the strengths of both summer insolation and the East Asian summer monsoon have determined the relative abundance of planktic foraminifer fauna and the SSTs of the western SCS for the last $135 \mathrm{kyr}$;

4. Our record revealed that the distinctive cold events in the MIS 5 in the SCS were due to the enhancement of East Asian winter monsoon intensity. One pronounced event of abrupt cooling occurred around $\sim 14$ kya, when warm/ humid vegetation and climate characterized the Southern Hemisphere, apparently driven by "cross-hemisphere flow" on a more spatial scale.

Acknowledgements We thank two anomalous reviewers for their comments and helpful reviews. This study was supported by grants from the Taiwan IMAGES Program and the National Science Council (NSC95-2611-M-019-012 \& NSC95-2611-M-019-013), and the National Taiwan Ocean University, Republic of China. For curation and sample preparation services, we are most grateful to the National Core Repository \& Laboratory located at the National Taiwan Ocean University and funded by the Center for Ocean Research (NCOR), National Science Council, Taiwan.

\section{REFERENCES}

An, Z., S. C. Porter, J. E. Kutzbach, X. Wu, S. Wang, X. Liu, X. Li, and W. Zhou, 2000: Asynchronous Holocene optimum of the East Asian monsoon. Quat. Sci. Rev., 19, 743-762.

An, Z., Y. Huang, W. Liu, Z. Guo, S. Clemens, L. Li, W. Prell, Y. Ning, Y. Cai, W. Zhou, B. Lin, O. Zhang, Y. Cao, X. Qiang, H. Chang, and Z. Wu, 2006: Multiple expansions of $\mathrm{C}_{4}$ plant biomass in East Asia since $7 \mathrm{Ma}$ coupled with strengthened monsoon circulation. Geology, 33, 705-708.

Bard, E., F. Rostek, and G. Ménot-Combes, 2004: Radiocarbon calibration beyond $20,000{ }^{14} \mathrm{C}$ yr B.P. by means of planktonic foraminifera of the Iberian Margin. Quat. Res., 61, 204-214.

Bassinot, F., L. D. Labeyrie, E. Vincent, X. Quidelleur, N. J. Shackleton, and Y. Lancelot, 1994: The astronomical theory of climate and the age of the Brunhes-Matuyama magnetic reversal. Earth Planet. Sci. Lett., 126, 91-108.

Bassinot, F., A. Baltzer, M. T. Chen, P. DeDeckker, W. Khuhnt, M. Levitan, D. Nurnberg, T. Oba, M. Prentice, M. Sanrthein, M. Situmorang, R. Tiedemann, A. Holbourn, T. Kiefer, U. Pflaumann, and S. Rothe, 2002: Scientific Report of the WEPAMA Cruise, MD122/IMAGES VII. Institut Francais pour la Recherche et la Technologie Polaires, 453 pp.

Bé, A. W. H., 1967: Foraminifera, families: Globigerinidae and Globorotaliidae. In: Fraser, J. H. (Ed.), Fiches d'Indentification du Zooplancton, Cons. Int. Explor. Mer, Charlottenlund, Denmark, Sheet 108.

Bé, A. W. H., 1977: An ecological, zoogeographical and taxonomic review of recent planktonic foraminifera. In: Ramsay, A. T. S. (Ed.), Oceanic micropaleontol., 1, Aca- 
demic Press, London, 1-100.

Bé, A. W. H. and D. S. Tolderlund, 1971: Distribution and ecology of living planktonic foraminifera in surface waters of the Atlantic and Indian Oceans. In: Funnel, B. M. and W. R. Riedel (Eds.), The micropaleontol. of oceans, Cambridge Univ. Press, 105-149.

Bé, A. W. H. and W. H. Huston, 1977: Ecology of planktonic foraminifera and biogeographic patterns of life and fossil assemblages in the Indian Ocean. Micropaleontology, 23, $369-414$

Beaufort, L., T. de Garidel-Thoron, B. Linsley, D. Oppo, and N. Buchet, 2003: Biomass burning and oceanic primary production estimates in the Sulu Sea area over the last $380 \mathrm{kyr}$ and the East Asian monsoon dynamics. Mar. Geol., 201, 53-65.

Chen, M. T. and W. L. Prell, 1997: Reassessment of CLIMAP methods for estimating Quaternary sea-surface temperatures: Examination using Pacific coretop data sets. Terr. Atmos. Ocean. Sci., 8, 111-139.

Chen, M. T. and C. Y. Huang, 1998: Ice-volume forcing of winter monsoon climate in the South China Sea. Paleoceanography, 13, 622-633.

Chen, M. T., L. Beaufort, and the Shipboard Scientific Party of the IMAGES III/MD106-IPHIS Cruise (Leg II), 1998: Exploring Quaternary variability of the East Asian monsoon, Kuroshio Current, and the Western Pacific warm pool systems: High-resolution investigations of paleoceanography from the IMAGES III/MD106-IPHIS cruise. Terr. Atmos. Ocean. Sci., 9, 129-142.

Chen, M. T., C. H. Wang, C. Y. Huang, P. Wang, L. Wang, and M. Sarnthein, 1999: A late Quaternary planktonic foraminifer fauna record of rapid climatic changes from the South China Sea. Mar. Geol., 156, 85-108.

Chen, M. T., L. J. Shiau, P. S. Yu, T. C. Chiu, Y. G. Chen, and K. Y. Wei, 2003: 500,000-year records of carbonate, organic carbon, and foraminiferal sea-surface temperature from the southeastern South China Sea (near Palawan Island). Palaeogeog. Palaeoclimatol. Palaeoecolog., 197, 113-131.

Chen, M. T., C. C. Huang, U. Pflaumann, C. Waelbroeck, and M. Kucera, 2005: Estimating glacial western Pacific seasurface temperature: methodological overview and data compilation of surface sediment planktic foraminifer faunas. Quat. Sci. Rev., 24, 1049-1062.

de Garidel-Thoron, T., L. Beaufort, B. K. Linsley, and S. Dannenmann, 2001: Millennial-scale dynamics of the East Asian winter monsoon during the last 200,000 years. Paleoceanography, 16, 1-12.

Fairbanks, R. G., M. Sverdlove, R. Free, P. H. Wiebe, and A. W. H. Bé, 1982: Vertical distribution and isotopic fractionation of living planktonic foraminifera from the Panama Basin. Nature, 298, 841-844.

Feldberg, M. J. and A. C. Mix, 2002: Sea-surface temperature estimates in the southeast Pacific based on planktonic foraminiferal species: Modern calibration and Last Glacial
Maximum. Mar. Micropaleontol., 44, 1-29.

Hemleben, C., M. Spindler, and O. R. Anderson, 1989: Modern planktonic foraminifera, Springer-Verlag, $363 \mathrm{pp}$.

Howell, P., 2001: ARAND time series and spectral analysis package for the Macintosh, Brown University.

Huang, B., Z. Jian, X. Cheng, and P. Wang, 2002: Foraminiferal responses to upwelling variations in the South China Sea over the last 220,000 years. Mar. Micropaleontol., 47, 1-15.

Imbrie, J. and K. G. Kipp, 1971: A new micopaleontological method for quantitative paleoclimatology: Application to a late Pleistocene Caribbean core. In: Turekian, K. K. (Ed.), The late Cenozoic glacial ages, Yale Univ. Press, New Haven, 71-181.

Jian, Z., B. Li, U. Pflaumann, and P. Wang, 1996: Late Holocene cooling event in the western Pacific. Sci. China Ser. $D, \mathbf{3 9}, 543-550$.

Jian, Z., B. Huang, W. Kuhnt, and H. L. Lin, 2001: Late Quaternary upwelling intensity and East Asian monsoon forcing in the South China Sea. Quat. Res., 55, 363-370.

Johnson, K. R., B. L. Ingram, W. D. Sharp, and P. Z. Zhang, 2006: East Asian summer monsoon variability during Marine Isotope Stage 5 based on speleothem $\partial^{18} \mathrm{O}$ records from Wanxiang Cave, central China. Palaeogeog. Palaeoclimatolog. Palaeoecolog., 236, 5-19.

Kershaw, A. P., S. van der Kaars, and P. T. Moss, 2003: Late Quaternary Milankovitch-scale climatic change and variability and its impact on monsoonal Australasia. Mar. Geol., 201, 81-95.

Kipp, N. G., 1976: New transfer function for estimating past sea-surface conditions from sea-bed distribution of planktonic foraminiferal assemblages in the North Atlantic. Mem. Geol. Soc. Am., 145, 3-41.

Kucera, M., M. Weinelt, T. Kiefer, U. Pflaumann, A. Hayes, M. Weinelt, M. T. Chen, A. C. Mix, T. T. Barrows, E. Cortijo, J. Duprat, S. Juggins, and C. Waelbroeck, 2005: Reconstruction of sea-surface temperatures from assemblages of planktonic foraminifera: Multi-technique approach based on geographically constrained calibration data sets and its application to glacial Atlantic and Pacific Oceans. Quat. Sci. Rev., 24, 951-998.

Kuo, N. J., Q. Zheng, and C. R. Ho, 2000: Satellite observation of upwelling along the western coast of the South China Sea. Remote Sens. Environ., 74, 463-470.

Lee, M. Y., K. Y. Wei, and Y. G. Chen, 1999: High resolution oxygen isotope stratigraphy for the last 150,000 years in the southern South China Sea: Core MD972151. Terr. Atmos. Ocean. Sci., 10, 239-254.

Li, B., Z. Jian, and P. Wang, 1997: Pulleniatina obliquiloculata as a paleoceanographic indicator in the southern Okinawa Trough during the last 20,000 years. Mar. Micropaleontol., 32, 59-69.

Lin, Y. S., K. Y. Wei, I. T. Lin, P. S. Yu, H. W. Chiang, C. Y. Chen, C. C. Shen, H. S. Mii, and Y. G. Chen, 2006: The Holocene Pulleniatina Minimum Event revisited: Geochemical and faunal evidence from the Okinawa Trough 
and upper reaches of the Kuroshio Current. Mar. Micropaleontol. 59, 153-170.

Liu, K. K., S. Y. Chao, P. T. Shaw, G. C. Gong, C. C. Chen, and T. Y. Tang, 2002: Monsoon-forced chlorophyll distribution and primary production in the South China Sea: Observations and a numerical study. Deep-Sea Res. I, 49, 1387-1412.

Liu, Z., A. Trentesaux, S. Clemens, C. Colin, P. Wang, B. Huang, and S. Boulay, 2003: Clay mineral assemblages in the northern South China Sea: Implications for East Asian monsoon evolution over the past 2 million years. Mar. Geol., 201, 133-146.

Parker, F. L., 1962: Planktonic foraminiferal species in Pacific sediments. Micropaleontology, 8, 219-254.

Patrick, A. and R. C. Thunell, 1997: Tropical Pacific sea surface temperatures and upper water column thermal structure during the last glacial maximum. Paleoceanography, 12, 649-657.

Pflaumann, U. and Z. Jian, 1999: Modern distribution patterns of planktonic foraminifera in the South China Sea and western Pacific: A new transfer technique to estimate regional sea-surface temperatures. Mar. Geol., 156, 41-83.

Porter, S. C., 2001: Chinese loess record of monsoon climate during the last glacial-interglacial cycle. Earth-Sci. Rev., 54, 115-128.

Schonfeld, J. and H. R. Kudrass, 1993: Hemipelagic sediment accumulation rates in the South China Sea related to late Quaternary sea-level changes. Quat. Res., 40, 368-379.

Shaw, P. T. and S. Y. Chao, 1994: Surface circulation in the South China Sea. Deep-Sea Res. I, 41, 1663-1683.

Shaw, P. T., S. Y. Chao, K. K. Liu, S. C. Pai, and C. T. Liu, 1996: Winter upwelling off Luzon in the north-eastern South China Sea. J. Geophys. Res., 101, 16435-16448.

Steinke, S. and M. T. Chen, 2003: The spatial distribution patterns of Pulleniatina obliquiloculata in the South China Sea: implications of latitudinal differences in the strength of the East Asian winter monsoon intensity during the last glaciation, EGS - AGU - EUG Joint Assembly, Scientific Program, 327.

Steinke, S., M. Kienast, U. Pflaumann, M. Weinelt, and K. Stattegger, 2001: A high resolution sea-surface temperature record from the tropical South China Sea $(16,500-$ 3,000 yr B.P.). Quat. Res., 55, 352-362.

Steinke, S., M. Kienast, and T, Hanebuth, 2003: On the significance of sea-level variations and shelf paleo-morphology in governing sedimentation in the southern South China Sea during the last deglaciation. Mar. Geol., 201, 179206.

Stuiver, M., P. J. Reimer, and R. W. Reimer, 2005: CALIB RADIOCARBON CALIBRATION PROGRAM CALIB 5.0. [WWW program and documentation] (http://calib.qub .ac.uk/).

Sun, Y., S. C. Clemens, Z. An, and Z. Yu, 2005: Astronomical timescale and palaeoclimatic implication of stacked
3.6-Myr monsoon records from the Chinese Loess Plateau. Quat. Sci. Rev., 25, 33-48.

Szeremeta, N., F. C. Bassinot, C. Kissel, Y. Bault, K. Guibert, K. Dubois, C. Laj, and M. Pagel, 2000: Stretching of sedimentary series collected through piston coring: Evidences, implications and corrections. EOS Trans. AGU, 81, Fall Meet. Suppl..

Thompson, P. R., A. W. H. Bé, J. C. Duplessy, and N. J. Shackleton, 1979: Disappearance of pink-pigmented Globigerinoides ruber at $120,000 \mathrm{yr} \mathrm{BP}$ in the Indian and Pacific Oceans. Nature, 280, 554-558.

Thunell, R. C., Q. Miao, S. E. Calvert, and T. F. Pedersen, 1992: Glacial-Holocene biogenic sedimentation patterns in the South China Sea: Productivity variations and surface water $p \mathrm{CO}_{2}$. Paleoceanography, 7, 143-162.

Ujiié, H. and Y. Ujiié, 1999: Late Quaternary course changes of the Kuroshio Current in the Ryukyu Arc region, northwestern Pacific Ocean. Mar. Micropaleontol., 37, 23-40.

Ujiié, H., Y. Tanaka, and T. Ono, 1991: Late Quaternary paleoceanographic record from the middle Ryukyu Trench slope, northwest Pacific. Mar. Micropaleontol., 18, 115128.

Ujiié, Y., H. Ujiié, A. Taira, T. Nakamura, and K. Oguri, 2003: Spatial and temporal variability of surface water in the Kuroshio source region, Pacific Ocean, over the past 21,000 years: Evidence from planktonic foraminifera. Mar. Micropaleontol., 49, 335-364.

van der Kaars, S. and P. D. Deckker, 2002: A late Quaternary pollen record from deep-sea core Fr10/95, GC17 offshore Cape Range Peninsula, northwestern Western Australia. Rev. Palaeobot. Palynol., 120, 17-39.

Waelbroeck, C., L. Labeyrie, J. C. Duplessy, J. Guiot, M. Labracherie, H. Leclair, J. Duprat, 1998: Improving past sea surface temperature estimates based on planktonic fossil faunas. Paleoceanography, 13, 272-283.

Wang, L., M. Sarnthein, H. Erlenkeuser, J. Grimalt, P. M. Grootes, S. Heilig, E. Ivanova, M. Kienast, C. Pelejero, and U. Pflaumann, 1999: East Asian monsoon climate during the late Pleistocene: High-resolution sediment records from the South China Sea. Mar. Geol., 156, 245-284.

WOA, 1998: World Ocean Atlas 1998, version 2, http:// www.nodc.noaa.gov/oc5/woa98.html. Technical report, National Oceanographic Data Center, Silver Spring, Maryland.

Wyrtki, K., 1961: Physical oceanography of the south-east Asian waters. NAGA Report Vol. 2, Scientific Results of Marine Investigations of the South China Sea and the Gulf of Thailand. Scripps Institution of Oceanography, La Jolla, CA, 195 pp.

Wyrtki, K., 1966: Oceanography of the eastern equatorial Pacific Ocean. Oceanogr. Mar. Biol. Ann. Rev. , 4, 33-68.

Wyrtki, K., 1977: Advection in the Peru Current as observed by satellite. J. Geophys. Res., 82, 3939-3943.

Yu, P. S., C. C. Huang, Y. Chin, H. S. Mii, and M. T. Chen, 2006: Late Quaternary East Asian monsoon variability in 
the South China Sea: Evidence from planktonic foraminifera faunal and hydrographic gradient records. Palaeogeog., Palaeoclimatol., Palaeoecolog., 236, 74-90.

Yuan, D., H. Cheng, R. L. Edwards, C. A. Dykoski, M. J. Kelly, M. Zhang, J. Qing, Y. Lin, Y. Wang, J. Wu, J. A. Dorale, Z. An, and Y. Cai, 2004: Timing, duration, and transitions of the last interglacial Asian monsoon. Science, 304, 575-578.

Zhao, M., C. Y. Huang, C. C. Wang, and G. Wei, 2006: A millennial-scale $\mathrm{U}_{37}{ }^{\mathrm{K}}$ 'sea-surface temperature record from the South China Sea $\left(8^{\circ} \mathrm{N}\right)$ over the last $150 \mathrm{kyr}$ : Monsoon and sea-level influence. Palaeogeog. Palaeoclimatol. Palaeoecolog., 236, 39-55. 